\title{
The Importance of Information Literacy for Asian Students at European Universities: Outlines
}

\author{
Zuza Wiorogórska \\ University of Warsaw, Warsaw
}

\section{Introduction}

The Bologna Process enabled the standardization of educational process at European Universities. The Erasmus program has been facilitating the mobility of students within the European Union (EU) for thirty years now. The growing number of international, European students resulted in establishing the variety of courses taught in English. It seems that European universities are now dealing well with the so-called Erasmus students.

The next challenge is internationalization. The universities want to go global both in the field of research and didactics. They open their doors for the students from beyond the EU, hence currently we observe a growing number of Eastern and Southeastern Asian ${ }^{1}$ students at European universities. In developing countries good education leads automatically to a bright future, being the only hope for social advance (Tripathi, Chand, Sonkar, és Jeevan, 2017). In Asian countries it is critical for the young and most productive age groups to be well equipped with knowledge and technical skills. The proportion of population attending universities is a very important indicator of future prosperity of developing society (Vu, Le, és Muhajarine, 2013). The graduates of European universities are expected to be the core of political, educational, and business elite of their countries, occupying top positions.

However, Asian students coming to European universities face at once not only a culture shock but also a linguistic one. They must learn in English and their teachers are mostly not English native-speakers. Thus, although English is an international language and a basic tool for communication and for the acquisition of academic knowledge and skills, it does not guarantee the absolute, mutual understanding. Moreover, Eastern and Southeastern Asian collectivist societies operate on the Confucian concept of Asian values. So, shortly, what may seem strange to a European, may be usual to an Asian. And vice versa.

\footnotetext{
1 Each time when I use adjective „Asian” in this paper, I mean Eastern Asia and Southeast Asia. Thus, all cultural, social, religious, or philosophical concepts discussed in this paper refer to these regions and societies of Asia.
} 
Most often this problem statement closes with the summing up sentence "these are cultural differences". And in spite of searching for their roots and for the solutions, Asian students are perceived as specific ones, and teachers and peers are waiting for their self-adaptation to the European culture, education system, and teaching styles.

In this paper I argue (1) for the work on cultural differences and efforts to understand them by the educators, in case of this paper-academic librarians; (2) I advocate for empowering the incoming Asian students with information literacy skills, equipping them in strong information tools that would allow them to feel self-confident in searching for reliable, evaluated information and would help them understand how the cultural differences are produced, and then deal better with the classroom behaviors of teachers and peers, the discussed topics, ameliorate their communication skills at European universities.

\section{Theoretical considerations on cultural issues}

The theoretical framework of my approach is built on: (1) an expanded and updated in 2015 American Library Association's definition of information literacy:

Information literacy is the set of integrated abilities encompassing the reflective discovery of information, the understanding of how information is produced and valued, and the use of information in creating new knowledge and participating ethically in communities of learning (Association of College and Research Libraries, 2015);

(2) The concepts of cultural literacy and Asia literacy suggested by Harry Irwin (Irwin, 1996): Asia literacy is knowledge, understanding and sensitivity about Asia in all its diversity and the ability to use it, as an individual or an organization, to communicate comfortably and effectively in Asia or with Asians in Australia. This country is mentioned here not without a reason. First, Irwin is Australian, so he was building his theory from this perspective. Second, Australia (and New Zealand) were first overseas countries that accepted a big wave of Asian immigration after the World War II and during Asian economic crisis of 1980s., so the country faced the need of intensive work on cross-cultural psychology to facilitate social integration of new habitants. Irwin's concept of cultural literacy focuses on learning salient characteristics and basic social and business skills of different cultures. From today's perspective we can say that it is close to the issues of cross-cultural psychology, a branch of psychology that has been growing in importance since the 1970s. 
Both Asia literacy and cultural literacy align well with the phenomenon of "other" or "new" literacies related to information literacy perceived as umbrella concept. A coherent overview of the new literacies can be found for example in (Koltay, Spiranec, és Karvalics, 2016).

(3) Three socio-cultural phenomena distinguishing Asia. These are: Confucianism, collectivism, and large power distance. They also influence on education and information literacy of Asian students.

\section{Confucianism}

It is a vast and reflective philosophical traditions that has been developing since the $7^{\text {th }}$ century BC and went through different periods, movements, and geopolitical contexts in Southeastern Asian countries. In the Confucian tradition, one must follow the way of self-cultivation and self-maturation that comprises all the aspects of life (Stępień, 2012). There exist several social norms that should not be broken, including respect for elders and parents. Confucianism has a strong reflection also in education: in respect for teachers, teacher-centered education, where teacher is a source and director of knowledge and $\mathrm{s} / \mathrm{he}$ should not be questioned or argued with (Vo, 2014).

\section{Collectivism}

It is founded on serving the group. The goals of the group are valued over those of individual, with respect for authority, hierarchical roles, and relationships. Collective reflection in education can be summed up in a statement that it is more important to be the same as everyone else than to emphasize special knowledge. Thus, often Western teachers face the lack of students' individual engagement during classes. Also, the notion of Asian values coined by Asian intellectuals in the 1990s., often linked to the human rights, was built upon collective values and on the opposition to Western individualism (Wacławczyk, 2013). Some authors (ex. Laungani, 2007) use the notion communalism while referring to family- and community-oriented society in East Asia (mainly India), but in fact the features describing communalist do not differ from those describing collectivism.

Large power distance

Power distance is a term used first by Geert Hofstede, a pioneer of cross-cultural psychology. Power distance is one of the five culture dimensions defined by Hofstede. It is the way in which power is distributed and the extent to which the lower ranking individuals accept unequal distribution. In Asia we observe 
inequality in power distribution; the majority of Asian countries are large power distance ones (Boski, 2009).

\section{Cultural influences on information literacy and information behavior}

Cultural and linguistic differences can affect information literacy (Al-Muomen, Shaw, és Courtney, 2016). Asian students lack critical thinking skills, they are expected to receive information passively and learn all information given and not selected one. They do not use many sources while learning but usually limit to one. They do not often understand what plagiarism means. This is not a simple lack of knowledge on copyright and intellectual property issues. Confucius said "Who copies the big master, shows respect to him". Confucianism declares the primacy of natural law $[\mathrm{Li}]$, based on moral rules over the positive law $[\mathrm{Fa}]$. According to these rules, copying and imitating of someone else's works were perceived as an indispensable element of cultural development of society. The authors themselves accepted this way of expressing respect and recognition to them (Jankowska, 2010).

Also, progressive Western teaching methods often do not work with Asian students, they often find it difficult to adapt to Western teaching and learning styles (Nguyen, 2011). Asian students sit quietly and listen attentively to the teacher. This kind of behavior is often misinterpreted as the lack of enough knowledge to take part in discussion or passivity. In fact, this is the way how the students express their respect to teacher. Hierarchy both in social and education system still plays an important role (Nguyen, 2011). What Hall (1977) defined as high- and low- context culture (Eastern and Western culture respectively) is not without meaning, too. In communication of a high-context culture very little information is transmitted in the coded, explicit part of the message, what is opposite to the communication in a low-context culture, where information is transferred in the explicit code. Also, the reaction on culturally inappropriate topics in Asia results in opinion that Asian students' general knowledge is not scholarly enough. Although globalization has influenced Asia (and helped Asian countries develop very fast), there are still many topics that remain $t a-$ boo. Asking Asian students about their opinion on, e.g., religion, war, poverty, or political system in their countries makes them uncomfortable.

Even though Asian universities are undergoing evolution in response to global education systems transformations, there are still the core, superior values important for Asian societies, therefore some changes cannot be applied entirely and immediately. It cannot be taken for granted that young Asians who 
decide to study at European universities think in the same or similar way to their European peers.

\section{Asian students at Western universities}

There are several studies on international students' information literacy, search skills, or library experience. The majority were conducted in Australian and North American universities. Some of those studies focused on Asian, mainly Chinese, students (Ishimura, 2013; Ishimura, Howard, és Moukdad, 2007; Lewis, 1969; Liu és Winn, 2009; Mu, 2007; Zhang, 2006). The other studies found in the literature dealt with international students generally, however, in line with the current trends at the universities in the Anglosphere, the big group of respondents to those ones were also Asian students (Abdoulaye, 2002; Ferrer-Vinent, 2010; Hughes, 2005, 2010; Liao, Finn, és Lu, 2007; Martin, Maxey-Harris, Graybill, és Rodacker-Borgens, 2009; Onwuegbuzie és Jiao, 1997; Saw, Abbott, Donaghey, és McDonald, 2013; Son és Park, 2014).

In general, much effort was made to assess the information literacy level of these students and to identify the gaps in their library-oriented knowledge rather than to define the reasons of this situation.

In this paper I focus on ways of coping with differences in patterns of thinking, learning, reasoning, laws and rules. I attempt to indicate how academic libraries, by identifying students' cultural background and offering a tailored information literacy education, may help Asian students adapt to Western teaching and learning styles and face academic and cultural challenges.

\section{Information literacy in multicultural context and a new role for academic libraries}

All the factors discussed above should influence the construction of strategies, applied to information literacy education dedicated to Asian students coming at European universities. Paraphrasing Laungani's statement-good research is not done in a social vacuum (Laungani, 2007. p. 99) - good teaching must be done in sociocultural context. A prior knowledge is needed to make sense of certain situations or behaviors.

Academic libraries could become buffers between students and learning environment. To effectively empower Asian students in information literacy skills, first librarians need to identify students' cultural background. To do so, 
they need to be able to define what Hall (1977) named cultural unconscious and understand out-of-awareness cultural processes. Hence, they need to learn more about the cultures represented by the students as well as learn more about the processes of students' analysis. Probably an intercultural training for information professionals, like the one suggested by Qayyum (2012), would be useful. It could also help in better analysis of students' work outcomes according to cultural models.

Academic libraries of those universities where many international students are enrolled could consider designing multi-lingual information access tools, like those tested and recommended by Nzomo, Ajiferuke, Vaughan, és McKenzie (2016).

And then, well-equipped in cultural, contextual knowledge, the librarians would prepare a tailored information literacy education program, patterned on already existing studies conducted by colleagues from the Anglosphere but adjusted to European educational context.

\section{Summary}

Undoubtedly, considering the topic of information literacy in cultural context is one of the current trends in studies of information users' and still remains to be discovered more deeply. As mentioned before, not little has been already done in Australia and North America. However academic environments of those countries have a common denominator which is English as the official language and so the language of didactics and all the tools in educational milieu (like e.g. library catalogs or information resources). In Europe the situation differs. English is not widely spoken in the majority of EU countries, so incoming international students and university staff must communicate in the language which is not a mother tongue for neither part of the didactic process. The application of the information literacy concepts and tools, theories of information studies and cross-cultural psychology as well as research methods in LIS and, wider, in social sciences might motivate academic libraries to establish successful programs of support for Asian students to assist in their study adventure at European universities and in life-long learning process after completion of university education. 


\section{References}

Abdoulaye, K. (2002): Information-Seeking Behaviour of African Students in Malaysia: a research study. Information Development, 18(3), 191-195. https://doi.org/10.1177/026666602400837284

Al-Muomen, N., Shaw, D., és Courtney, M. (2016): "How will I know?" engagement with information resources: A comparison of undergraduates at Indiana and Kuwait Universities. Library Review, 65(4/5), 242-254. https:// doi.org/10.1108/LR-12-2015-0120

Association of College and Research Libraries. (2015): Framework for Information Literacy for Higher Education. Retrieved from http:/www.ala.org/ acrl/standards/ilframework

Boski, P. (2009): Kulturowe ramy zachowań spolecznych. Podręcznik psychologii międzykulturowej. Warszawa: Wydawnictwo Naukowe PWN - Academica Wydawnictwo SWPS.

Ferrer-Vinent, I. J. (2010): For English, Press 1: International Students' Language Preferences at the Refence Desk. The Reference Librarian, 51, 189201. https://doi.org/10.1080/02763871003800429

Hall, E. T. (1977): Beyond culture. New York: Anchor Books.

Hughes, H. (2005): Actions and Reactions: Exploring International Students' Use of Online Information Resources. Australian Academic és Research Libraries, 36(4), 169-179. https://doi.org/10.1080/00048623.2005.10755308

Hughes, H. (2010): International Students' Experiences of University Libraries and Librarians. Australian Academic és Research Libraries, 41(2), 77-89. https://doi.org/10.1080/00048623.2010.10721446

Irwin, H. (1996): Communicating with Asia. Understanding people and customs. St. Leonards, NSW, Australia: Allen és Unwin.

Ishimura, Y. (2013): Information Behavior and Japanese Students: How Can an Understanding of the Research Process Lead to Better Information Literacy? Public Services Quarterly, (9), 20-33. https://doi.org/10.1080/15228959.20 13.758977

Ishimura, Y., Howard, V., és Moukdad, H. (2007): Information literacy in academic libraries: assessment of Japanese students' needs for successful assignment completion in two Halifax universities. The Canadian Journal of Information and Library Science, 31(1), 1-26.

Jankowska, M. (2010): Pojęcie autora oraz prawo do autorstwa utworu w wybranych systemach prawnych państw azjatyckich. In J. Marszałek-Kawa (Ed.), Wartości azjatyckie. Polityka i prawa człowieka. Toruń: Wydawnictwo Adam Marszałek (pp. 361-390): Toruń: Wydawnictwo Adam Marszałek. 
Koltay, T., Spiranec, S., és Karvalics, L. Z. (2016): Research 2.0 and the future of information literacy. Amsterdam [etc.]: Elsevier: Chandos Publishing.

Laungani, P. D. (2007): Understanding cross-cultural psychology. Eastern and Western perspectives. London: Sage.

Lewis, M. G. (1969): Library Orientation for Asian College Students. College és Research Libraries, 30(3), 267-272.

https://doi.org/10.5860/crl_30_03_267

Liao, Y., Finn, M., és Lu, J. (2007): Information-Seeking Behavior of International Graduate Students vs. American Graduate Students: A User Study at Virginia Tech 2005. College és Research Libraries, 68(1), 5-25.

Liu, G., és Winn, D. (2009): Chinese Graduate Students and the Canadian Academic Library: A User Study at the University of Windsor. The Journal of Academic Librarianship, 35(6), 565-573.

https://doi.org/10.1016/j.acalib.2009.08.001

Martin, C. K., Maxey-Harris, C., Graybill, J. O., és Rodacker-Borgens, E. K. (2009): Closing the Gap: Investigating the Search Skills of International and US Students: An Exploratory Study. Library Philosophy and Practice, (October). Retrieved from https://digitalcommons.unl.edu/cgi/viewcontent. cgi?referer=https://www.google.pl/éshttpsredir=1ésarticle=1303éscontex$\mathrm{t}=$ libphilprac

$\mathrm{Mu}, \mathrm{C}$. (2007): Marketing academic library resources and information services to international students from Asia. Reference Services Review, 35(4), 571583. https://doi.org/10.1108/00907320710838390

Nguyen, C. T. (2011): How are cultural influences reflected in perceptions of Vietnamese students studying at Australian universities? In T. Desmond (Ed.), The Asian Conference on Education 2010 - "Globalisation or Internalisation?" . December 2-5 2010, Osaka, Japan. Official Conference Proceedings (pp. 763-774): Osaka: The International Academic Forum. Retrieved from http://papers.iafor.org/conference-proceedings/ACE/ ACE2010_proceedings.pdf

Nzomo, P., Ajiferuke, I., Vaughan, L., és McKenzie, P. (2016): Multilingual Information Retrieval és Use: Perceptions and Practices Amongst Bi/Multilingual Academic Users. Journal Of Academic Librarianship, 42(5), 495-502. https://doi.org/10.1016/j.acalib.2016.06.012

Onwuegbuzie, A. J., és Jiao, Q. G. (1997): Academic library usage: a comparison of native and non-native English-speaking students. The Australian Library Journal, 46(3), 258-269. https://doi.org/10.1080/00049670.1997.1 0755807 
Qayyum, M. A. (2012): Designing and Intercultural Training Framework for Information Professionals. Reference és User Services Quarterly, 51(3), 226-230.

Saw, G., Abbott, W., Donaghey, J., és McDonald, C. (2013): Social media for international students - it's not all about Facebook. Library Management, 34(3), 156-174. https://doi.org/10.1108/01435121311310860

Son, J.-B., és Park, S.-S. (2014): Academic experiences of international PhD students in Australian higher education: From an EAP program to a $\mathrm{PhD}$ program. International Journal of Pedagogies and Learning, 9(1), 26-37. https://doi.org/10.1080/18334105.2014.11082017

Stępień, M. (2012): Confucianism 2.0. In J. Marszałek-Kawa (Ed.), Is the 21st Century The Age of Asia? Deliberations on culture and education (pp. 2041). Torun: Wydawnictwo Adam Marszałek.

Tripathi, M., Chand, M., Sonkar, S. K., és Jeevan, V. K. J. (2017): A brief assessment of researchers' perceptions towards research data in India. IFLA Journal, 43(1), 22-39. https://doi.org/10.1177/0340035216686984

Vo, T. H. Y. (2014): Cultural Differences: A Barrier to Native English Teachers in English as Foreign Language Contexts. VNU Journal of Foreign Studies, $30(1), 63-72$.

Vu, L. T. H., Le, L. C., és Muhajarine, N. (2013): Multilevel Determinants of Colleges/Universities Enrolment in Vietnam: Evidences from the 15\% Sample Data of Population Census 2009. Social Indicators Research, 111, 375-386. https://doi.org/10.1007/s11205-012-0011-2

Wacławczyk, W. (2013): The Western View of Human Rights and "Asian Values." In J. Marszałek-Kawa (Ed.), Dilemmas of contemporary Asia : deliberations on culture and education (pp. 98-109). Toruń: Wydawnictwo Adam Marszałek.

Zhang, L. (2006): Communication in academic libraries: an East Asian perspective. Reference Services Review, 34(1), 164-176. https://doi. org/10.1108/00907320610648842 


\begin{abstract}
European universities have opened their doors to the students from beyond European Union, mostly from Asian countries. However, students coming to Europe may face at once not only a culture shock but also a linguistic and informational one. In this paper I (1) briefly explain the cultural background of Asian students; (2) argue for the work on cultural differences to understand them by the European educators; (3) advocate for empowering the incoming students with information literacy skills, to allow them to feel self-confident in searching for reliable, evaluated information; to help them understand how the cultural differences are produced, so they can deal better with the classroom behaviors of teachers and peers, the discussed topics, and ameliorate their communication skills.
\end{abstract}

